\title{
Endocrine Integration of Fetal Ovaries Grafted under Kidney Capsule of Unilaterally or Bilaterally Orchidectomized Male Hamster
}

\author{
Integración Endocrina de Ovarios Fetales Trasplantados bajo la Cápsula \\ Renal de Hámster Machos Uni o Bilateralmente Castrados
}

In memoriam Dr. Jorge Arrau Escobar and Dr. Eduardo Bustos-Obregón

Luna, S. L.*; Peña, S. I.*; Cuevas, A. J.* \& Brown, D. I.**

LUNA, S. L.; PEÑA, S. I.; CUEVAS, A. J. \& BROWN, D. I. Endocrine integration of fetal ovaries grafted under kidney capsule of unilaterally or bilaterally orchidectomized male hamster. Int. J. Morphol., 34(4):1271-1279, 2016.

SUMMARY: Mammalian ovary development undergoes important changes during the perinatal period, moment when follicles are assembled and start to develop in a process not well known, involving endocrine and paracrine factors. In order to investigate the effect of two different hormonal environments on the early development of the ovary, we used an autologous transplant model in which Syrian hamster fetal ovaries were grafted under the kidney capsule of males hosts previously unilaterally or bilaterally orchidectomized. After 35 days of graft, ovaries and kidney parenchyme of the host male did not present signs of rejection. Ovaries contained primordial, primary follicles, secondary follicles and few tertiary follicles with morphological features similar to ovaries of control females of 35 days of age. Healthy primary and secondary follicles of experimental groups had frequency distribution and size similar to control ovaries but tertiary follicles were scarce in control as well as in grafts where they were mainly atretic. PCNA, marker of proliferation, was immuno detected in granulosa cells of growing follicles and the marker of apoptosis, Caspase 3 active, was evident mainly in secondary follicles. Immunoreactivity for steroidogenic proteins, StAR, 3- $\beta$ HSD and aromatase detected in the follicular wall cells and the decreased serum levels of FSH without important changes in testosterone in bilateral orchidectomized males that received ovarian graft, and testosterone decreased without changes in FSH levels in unilateral orchidectomized males (UO) with ovarian graft, all together suggest the effect of steroid hormones produced by the ovary. In conclusion, the experimental model of autologous transplant presents evidence of early ovary development under the kidney capsule and its functional integration to the endocrine axis of the host male.

KEY WORDS: Ovary; Folliculogenesis; Steroidogenesis; Ovarian graft; Hamster.

\section{INTRODUCTION}

Mammalian ovary development undergoes important changes during the perinatal period, moment when the functional unit, the ovarian follicle, is assembled and a finite pool of primordial follicles is defined (Hirshfield, 1991). Primordial follicle consists of an oocyte surrounded by a layer of few somatic cells, the pregranulosa cells. The fate of each follicle is controlled by different mechanisms involving endocrine and paracrine factors. Under signals not well understood, selective primordial follicles left this dormancy stage and starts to grow through primary and secondary stages before acquire an antral cavity (Greenwald
\& Roy, 1994; Richards, 1994; McGee \& Hsueh, 2000). Growing preantral follicles are responsives to endogenous and exogenous gonadotropins hormones as well as to oocyte and granulose derived factors (recently reviewed Hsueh et al., 2015). After that, early antral follicles undergo atresia, except some of these continue growing to a preovulatory stage supported by cyclic changes of pituitary FSH and LH. This follicular development will determine the production and release of the first wave of mature ovocytes during the initial ovulation in puberty, starting the fertile life of the female (Greenwald \& Roy).

\footnotetext{
* Escuela de Química y Farmacia, Facultad de Farmacia, Universidad de Valparaíso, Valparaíso, Chile.

${ }^{* * *}$ Laboratorio de Biología de la Reproducción y del Desarrollo, Instituto de Biología, Facultad de Ciencias, Universidad de Valparaíso, Valparaíso, Chile.
} 
Ovarian follicle also produce steroid hormones, androgens, estrogens and progesterone, that integrate the endocrine reproductive axis (Gore-Langton \& Armstrong, 1994). Acting on specific ovarian receptors, ovarian steroid hormones play important roles on regulation of the ovarian process like follicular growth, oocyte maturation and ovulation (Drummond, 2006). Progesterone regulates granulosa cell function and follicle rupture during ovulation (Graham \& Clarke, 1997). Androgens mainly produced by theca cells in response to $\mathrm{LH}$ act predominantly on granulosa cells promoting early follicular growth, but also stimulating apoptosis and atresia depending on the developmental status of the follicle and species studied. The intrafollicular effect of estrogens serves to stimulate the proliferation of granulosa cells in small preantral follicles and reduce atresia (Hsueh et al.). The importance of early ovary exposure to androgens has been considered the cause of follicular dysregulation that can be related to conditions affecting female fertility (Walters et al., 2008). In vivo models to study the hormonal effect on the early life of the female consist in administration of supraphysiological doses of chemical agents in single o multiple doses applied to small individuals, the procedure causing dosage uncertainties.

In the present study we used an autologous transplant model previously described by Arrau et al. (1983) in which Syrian hamster fetal ovaries (obtained the day before birth) were grafted under the kidney capsule of adult males. The ovaries can grow and differenciate in this ectopic setting, developing healthy follicles and germ cells, and can be responsive to exogenous testosterones and progesterone (Arrau et al.). In order to investigate the effect of two different hormonal environments on the post natal development of the ovary, we used male hosts previously orchidectomized unilaterally or bilaterally. We focused our aim on the ovarian grafted functionality, studying follicular development and expression of proteins involved in the steroidogenic pathway, as well as the integration of the ovarian grafts to the host male endocrine axis.

\section{MATERIAL AND METHOD}

Animals. Adult Syrian hamsters (Mesocricetus auratus) derived from a stock maintained at the Pontificia Universidad Católica de Chile were used in this experimental study. The animals were kept in a controled environment with artificial illumination (14 hours light and 10 hours darkness cycle) and under controlled temperature $\left(24^{\circ} \mathrm{C}\right)$. Tap water and commercial pellet food were supplied ad libitum. On the $15^{\text {th }}$ day of pregnancy females were euthanized to remove female pups, and their ovaries were removed (ovaries 15 p.c.d).
Adult males were divided in two experimental groups: unilaterally orchidectomized (UO) and bilaterally orchidectomized (BO). Sixty days after surgery, 6 males of each group were used as recipients of fetal ovaries graft, others were used to obtain blood for hormone determinations.

Fetal ovary transplantation was performed as previously described (Arrau et al.). Under anaesthesia with pentobarbital, one kidney of each host was exposed and 3-5 fetal ovaries were inserted under the kidney capsule. After 35 days, males were euthanized and the grafts with the surrounding renal tissue were processed by routine histological technique. Trunck blood was collected to obtain serum for hormone determination. Groups have been called $\mathrm{UO}+\mathrm{OG}$ for unilateral orchidectomized males receiving ovaries under kidney capsule, or BO+OG when bilateral orchidectomized males received the ovaries graft. As control for gonad development studies, 35 post natal days (p.n.d.) ovaries were used (C).

Histologic study. Grafts and surrounding tissue were fixed in Bouin Hollande solution, dehydrated in ethanol/butanol (Gabe, 1968) and processed by routine histological technique until to get permanent slides. Sections $(5 \mu \mathrm{m})$ were stained using a trichrome method, Arteta trichrome (Sitzmann et al., 2014) and analyzed in a bright field microscope. The ovarian follicles were classified according to morphological criteria as primary, secundary and tertiary follicles discriminating if they presented health or atresia features. A light binocular microscope with micrometric grid was used to classify and measure follicular diameter. The photomicrographs were obtained with a Leica Leitz DMRB brightfield microscope with a Leica DFC290 digital camera.

Immunohistochemistry. In order to study markers of cell activity, immunohistochemistry was used with specific antibodies on histologic sections following standard procedures, using biotinilated secondary antibodies and chromogenic detection with 3.3'-diaminobenzidine (DAB) until typical brown precipitate as reaction was obtained. Quantification by h-score methodology (Detre et al., 1995) of immunopositivity per area unit was developed using the Image J 1.6 Informatics Program by U.S. National Institutes of Health (NIH).

As a marker of cell proliferation, the proliferating cell nuclear antigen (PCNA) was immunodetected using a mouse monoclonal antibody anti rat (PCNA, clone PC10, NCL-PCNA, Novocastra, UK) (1:100 dilution). As apoptotic cell marker a large fragment of activated Caspase 3 was immunodetected with a rabbit polyclonal antibody anti Cleaved Caspase-3 antibody (9661, Cleaved Caspase-3, 
Asp175, Cell Signaling Technology, USA) (1:200 dilution). Steroidogenic tissue was identified through the following antibodies, a rabbit polyclonal anti human steroidogenic acute regulatory protein StAR (FL-285, sc-25806, Santa Cruz, USA) (1:250 dilution), goat polyclonal anti human 3 $\beta$-hydroxysteroid dehydrogenase, 33-HSD (P-18, sc-30820, Santa Cruz, USA) (1:500 dilution), and mouse anti human cytochrome P450 aromatase, clone H4 (MCA2077S, AbD Serotec, UK) (1:100 dilution).

Hormone Levels. In order to distinguish the endocrine environment in host males with and without grafts, FSH and testosterone levels in serum were quantified by radioimmunoassay (RIA). FSH RIA was performed using a double antibody technique following the protocol provided by the National Institute of Arthritis, Diabetes and Kidney Diseases (NIADDK). The results were expressed in terms of rat FSH (NIADDK-rFSH-RF-2). All the reagents used were donated by Dr. A. F. Parlow. Testosterone assay was performed using antiserum raised against testosterone linked at 3 position by carboxymethyl-oxime to bovine serum albumin. For testosterone RIA, serum samples were extracted with ether, and dextran-coated charcoal was used to separate free from bound hormone.

Data Analysis. Morphological data were expressed as mean \pm SEM and analyzed using ANOVA and Tukey-Kramer's comparison test. The comparison was statistically significant when $\mathrm{p}<0,05$. Hormone levels data were expressed as individual determinations.

\section{RESULTS}

Ovary graft morphology. Photomicrographs depicting ovarian growth are shown in Fig. 1A-C. Hamster fetal ovaries (15 p.c.d) grafted under kidney capsule of adult hamster UO and BO males 35 days before they received the graft, in both conditions, show similar development in comparison to ovaries of puberal females of 35 p.n.d.
Neither grafts nor kidney parenchyme of the host male presented fibrosis or leukocyte infiltration. Follicular compartment contained predominantly primordial follicles, primary follicles, secondary follicles and few tertiary follicles in $\mathrm{UO}+\mathrm{OG}$ and $\mathrm{BO}+\mathrm{OG}$ with morphological features similar to ovaries of control females of 35 d.p.n. (Table I and Fig. 1D-F). Comparisons of follicular frequency distribution showed no significant differences between healthy primary and secondary follicles of experimental groups and control ovaries (Fig. 1G). Tertiary follicles were scarce in control females of that age but when occasionally present in grafts, they were always atretic. Size of follicles expressed as measured diameter did not present significant differences between groups (Table I).

To determine if atretic process is affected by the hormonal status of the host, atretic primary and secondary follicles were morphologically discriminated (Fig. 1H). No significant differences were observed between grafted ovaries. But in UO+OG there were more secondary atretic follicles and less tertiary atretic follicles than the control. $\mathrm{BO}+\mathrm{OG}$ also presented less tertiary follicles than the control. The main morphological difference in ovaries of the three conditions $(\mathrm{C}, \mathrm{UO}+\mathrm{OG}$ and $\mathrm{BO}+\mathrm{OG})$ was that in 35 p.n.d hamster ovary several corpora lutea can be present, but no corpora lutea were observed in ovaries grafted in UO nor BO males.

Follicular growth. In order to objectify the follicular growth, cell proliferation and apoptosis were evaluated by immunohistochemistry. Immunoreactivity for PCNA was present mainly in granulosa cells of primary, secondary and terciary follicles of ovaries grafted under the kidney capsule of UO and BO males (Fig. 2A-I). H-score measurements indicate that PCNA immunoreactivity in secondary and tertiary follicles is lower in ovaries grafted in BO than ovaries grafted in UO males and controls respectively. Immunodetection of Caspase 3 active, as marker of apoptosis is evident mainly in secondary follicles (Fig. 2J-L) without differences between experimental groups.

Table I. Diameter of healthy follicles of ovaries grafted under kidney capsule of unilateral (UO) o bilateral orchidectomized adult males (BO). Media \pm E.E. (mm). BO: bilateral orchidectomized; GC: granulose cells; UO: unilateral orchidectomized

\begin{tabular}{llccc}
\hline $\begin{array}{l}\text { Follicle } \\
\text { classification }\end{array}$ & $\begin{array}{l}\text { Morphological } \\
\text { characterization }\end{array}$ & control ovary 35 p.n.d & ovary grafted in UO male & ovary grafted in BO male \\
\hline primary & $\begin{array}{l}\text { 1 cuboidal GC layer } \\
\text { no inner theca }\end{array}$ & $51 \pm 5$ & $56 \pm 3$ & $54 \pm 4$ \\
secondary & $\begin{array}{l}2-5 \text { GC layers } \\
+ \text { inner theca }\end{array}$ & $108 \pm 20$ & $92 \pm 10$ & $84 \pm 7$ \\
tertiary & $>6$ GC layers & & -- & --- \\
& ++ inner theca & $475 \pm 4$ & & \\
\hline
\end{tabular}




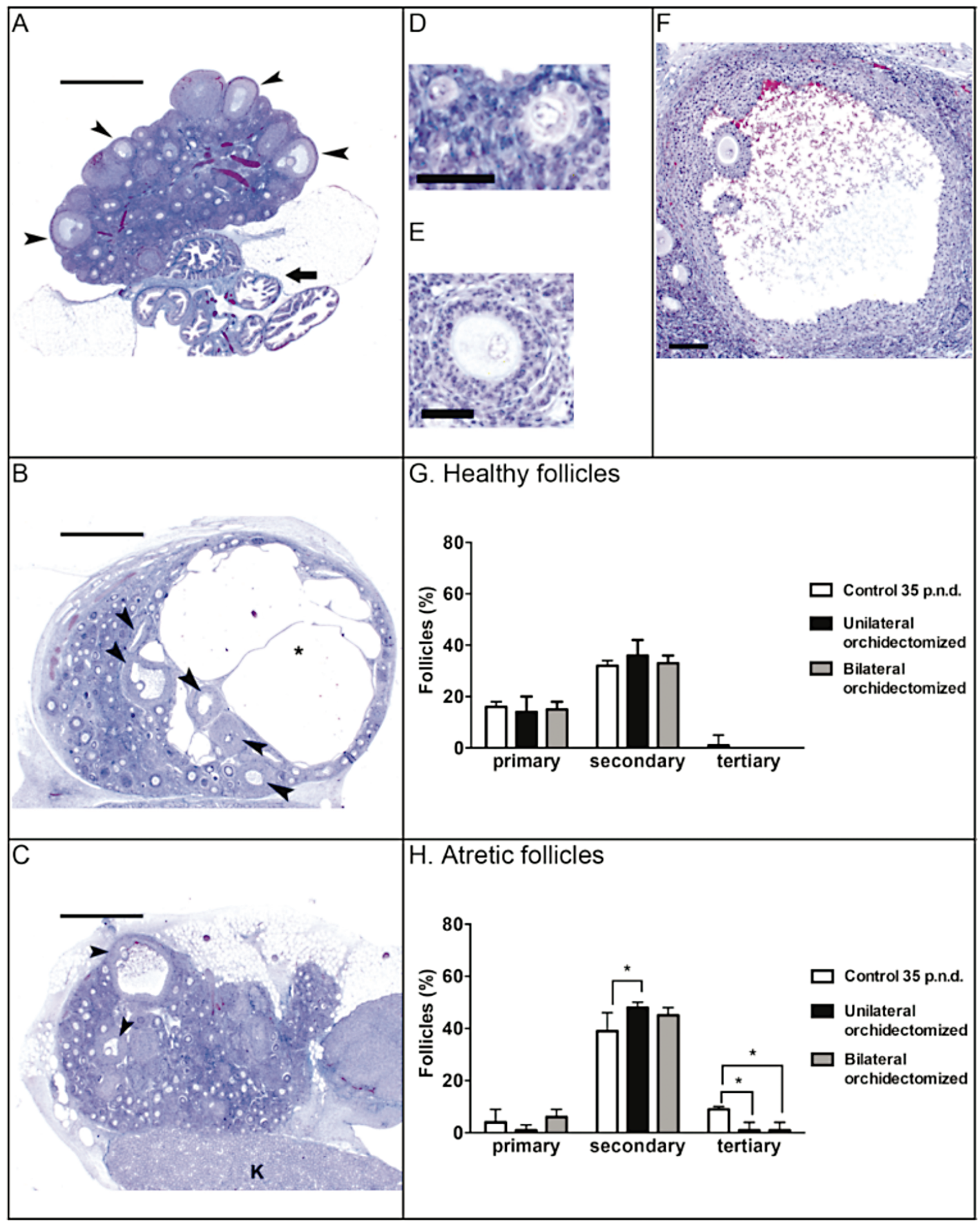

Fig. 1. General appearance of hamster fetal ovaries (15 days post coitum) grafted under kidney capsule of adult males, 35 days after transplantation. Host males were unilateral (UO) or bilateral orchidectomized (BO) 60 days before performing ovary graft. For comparison, normal ovaries of similar age (A), (35 p.n.d.) were used as control group. Arrowhead: antral follicle. Arrow: oviduct. Asterix: rete ovarii cyst. K: kidney. Ovarian grafts have developed to different stages of follicular growth in both experimental conditions (UO+OG and BO+OG). Details of primordial and primary (D), secondary (E) and tertiary follicles $(F)$ in the grafts show normal morphological features. Scale bars A-C=1 $\mu \mathrm{m} ; \mathrm{D}-\mathrm{E}=50 \mu \mathrm{m} ; \mathrm{F}=100 \mu \mathrm{m}$. Frequency distribution of healthy growing follicles presents no differences with control ovary of similar age (35 p.n.d) (G). Secondary and tertiary atretic follicles show differences with the control group $(\mathrm{H})$. Results are expressed as media \pm E.E. 


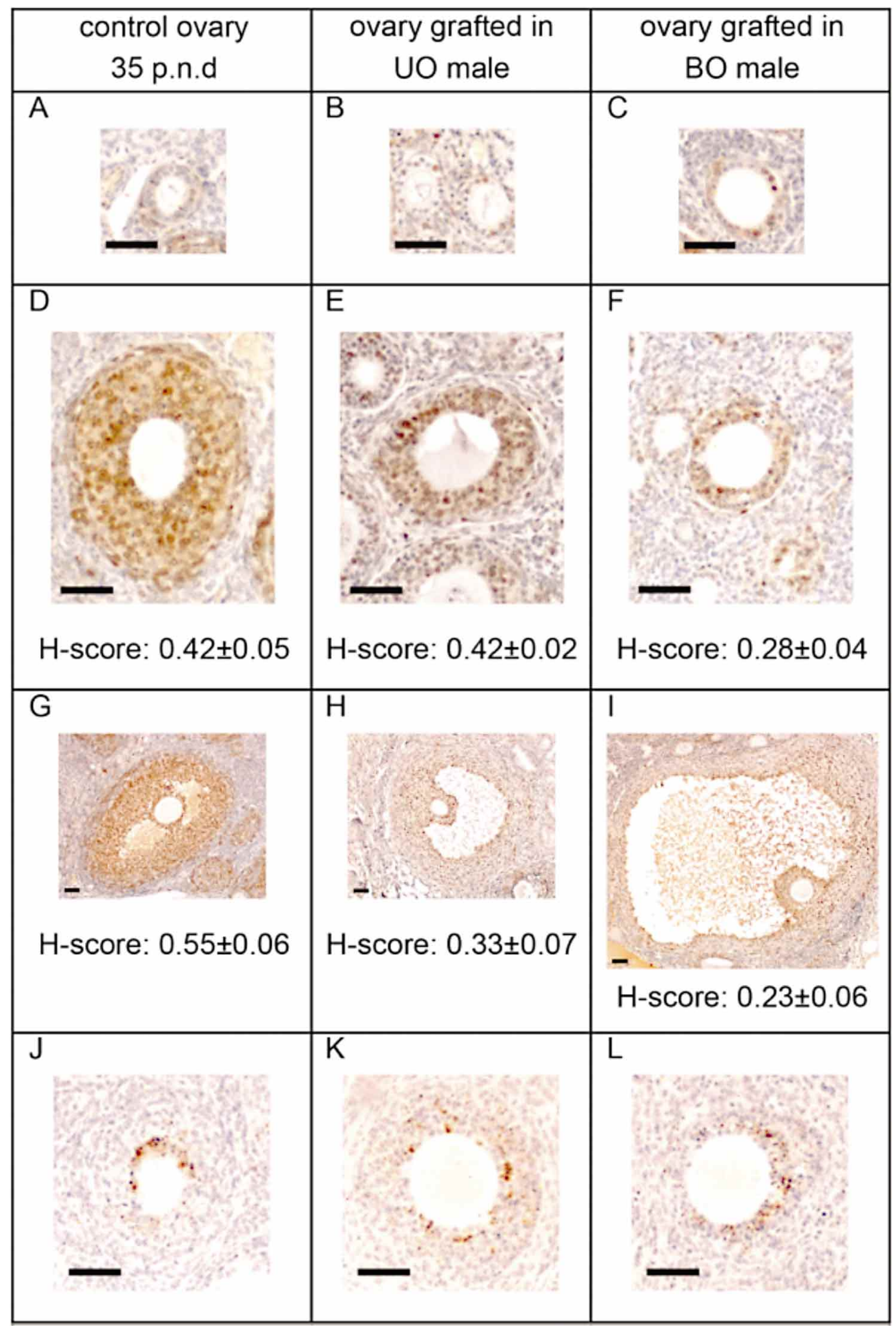

Fig. 2. Proliferation and apoptosis of granulosa cells in ovaries grafted under kidney capsule of adult males. Immunohistochemistry for PCNA show reactivity in primary follicles (A-C), secondary follicles (D-F) and tertiary follicles (G-I). Immunolocalization of Caspase-3 active as apoptosis marker is mainly evident in secondary follicles (J, K, L). Scale Bars: $50 \mu \mathrm{m}$. 
Steroidogenic pathway. StAR, steroidogenic acute regulatory protein, a transport protein that regulates cholesterol transfer within the mitochondria, and rate-limiting step in the production of steroid hormones was immunodetected in granulose cells of primary follicles and in theca cells of developing follicles in control ovary (Fig. 3A). But in grafted ovaries it was detected mostly in granulose cells of healthy and atretic follicles (Figs. 3B \& C).
Immunodetection of $3-\beta H S D$, the enzyme that catalyses the formation of progesterone and testosterone, shows strong reactivity in theca cells and interstitial cells around follicles in control ovaries (Fig. 3D), while an evident reactivity was observed in a well organized theca layer surrounding secondary and tertiary follicles in grafted ovaries (Figs. 3E \& F).

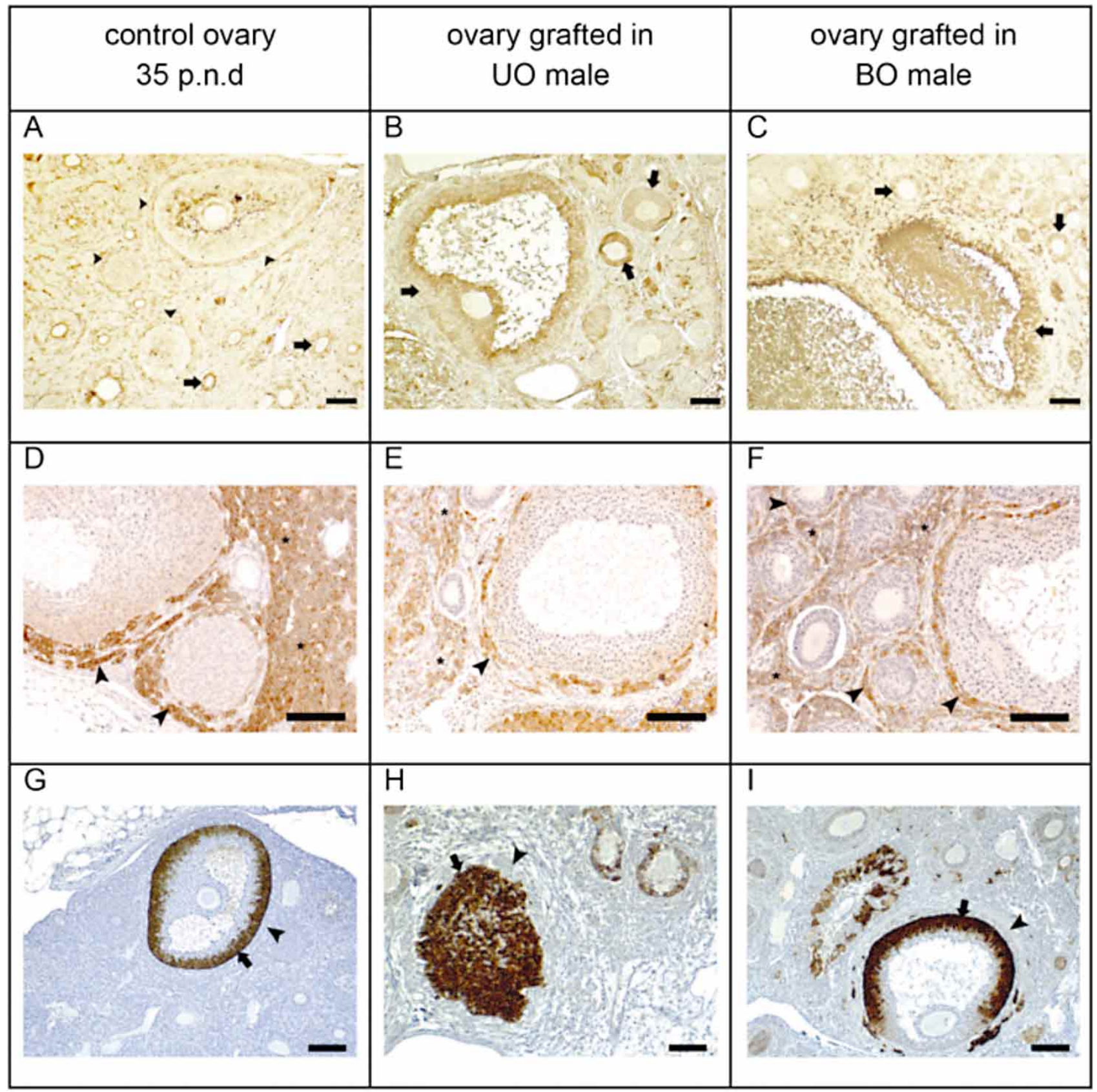

Fig. 3. Steroidogenic pathway of proteins expressed in ovaries grafted under kidney capsule of adult males. Immunoreactivity of StAR protein (A-C), 3ßHSD (D-F) and aromatase (G-I). Arrowhead: theca layer. Arrow: granulose layer. Asterix: Interstitial gland. Scale bars $=100 \mu \mathrm{m}$. 
Aromatase (CYP19), the enzyme that catalyses the conversion of testosterone to estradiol, was strongly immunodetected exclusively in granulosa cells of healthy follicles of control and grafted ovaries (Fig. 3G-I).

Hormone levels. In order to estimate the endocrine status of the animals, FSH and testosterone levels were measured with immunoassays (Fig. 4). For comparison, serum of intact adult hamster males (AM), unilateral and bilateral orchidectomized males without grafts were also measured. Fig. 4 depicts individual data of hormone concentration, showing that, as expected, bilateral orchidectomized males (BO) have FSH levels higher than intact ones, and testosterone levels are under detection limit. In unilateral orchidectomized males (UO) both hormones are near normal range. The development of ovary graft in $\mathrm{BO}(\mathrm{BO}+\mathrm{OG})$ produce evident changes in FSH levels without important changes in testosterone levels than $\mathrm{BO}$ without graft. In other ways UO males with ovaries grafted under the kidney capsule (UO+OG) showed lower levels of testosterone without important changes in FSH levels compared with UO males without grafts.
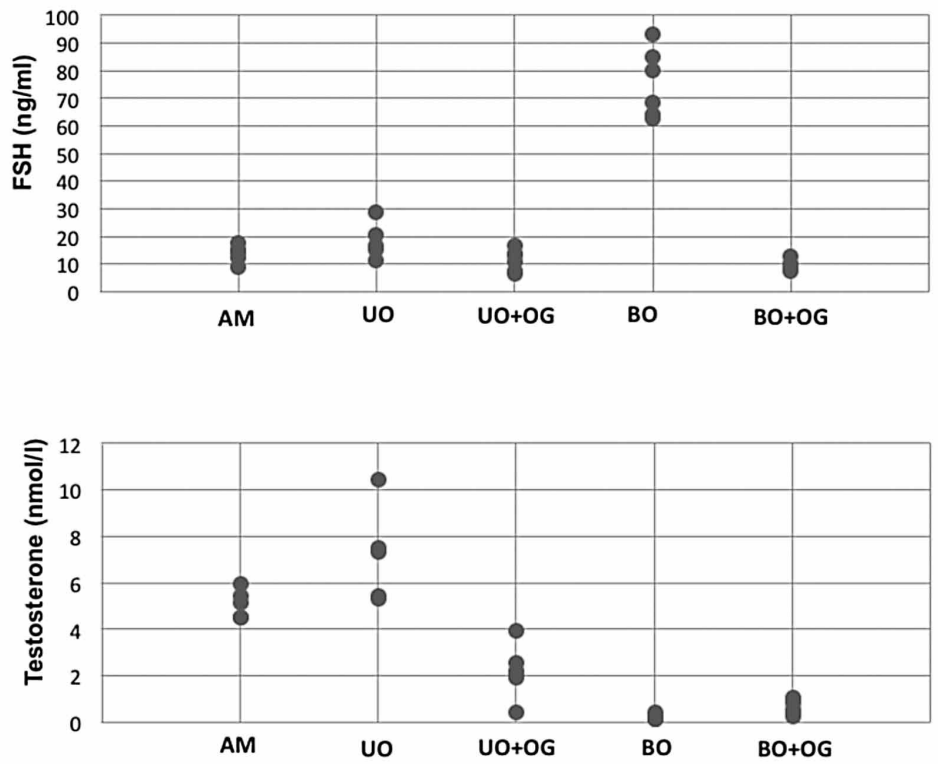

Fig. 4. FSH and testosterone levels in Syrian hamster males with or without ovary graft under the kidney capsule. Individual data of FSH and testosterone concentration in serum samples of intact adult males (AM), unilateral orchidectomized without graft (UO), unilateral orchidectomized with ovary graft $(\mathrm{UO}+\mathrm{OG})$, bilateral orchidectomized without graft $(\mathrm{BO})$ and bilateral orchidectomized with ovary graft $(\mathrm{BO}+\mathrm{OG})$

\section{DISCUSSION}

Studies in several species and in different experimental systems in vivo and in vitro have demonstrated that early ovary growth is influenced by the hormonal environment (McGee \& Hsueh; Hsueh et al.). Approaches with in vivo models have the difficulty to administer exogenous hormones in pups, while in vitro studies require isolation of the gonad to be exposed to controlled artificial media. In this work we evidence that fetal graft ovaries can develop and grow under the kidney capsule of adult males, allowing folliculogenesis and steroid hormone production, also integrating the endocrine axis of the host due to the change of their hormone levels.

In both experimental approaches $(\mathrm{UO}+\mathrm{OG}$ and $\mathrm{BO}+\mathrm{OG}$ ) ovaries obtained at the end of fetal period, grafted for 35 days showed follicular development from primordial to secondary with few antral follicles with similar follicular growth to control ovaries of 35 days of age. The ovarian tissue has been shown to be well adapted in ectopic places such as the anterior chamber of eye (Goodman, 1934), cheek pouch (Caldwell et al., 1966), subcutaneously (Chihal et al., 1976), under kidney capsule (Henzl et al., 1971; Mangoushi, 1977; Uilenbroek et al., 1978, Felicio et al., 1983) and intrasplenic (McGowan \& Davis, 1970; Uilenbroek et al.), being under the kidney capsule where best follicular development was obtained.

Several small animal models have been used to keep the female gonad out of their location. Experimental ovarian grafts were performed in rat (Goodman; Chihal et al.; Mangoushi; Uilenbroek et al.), mouse (Felicio et al.; Gosden et al., 1994), and hamster (Caldwell et al.; McGowan \& Davis; Henzl et al.; Gosden et al.). Syrian hamster can be considered the most successful system of allograft without immunosuppresor treatment and in a non-genetically modified animal. This feature seems to be based on the genetic homogeneity of this species since Mesocricetus auratus used as laboratory animals originated from offspring of three littermates, one male and two females, collected in Syria in 1930 (Fulton, 1968). In our study, allotransplants of whole fetal ovaries under the kidney capsule of adult Syrian hamster males presented development similar to control. Signs of massive atresia have not been found and the presence of healthy follicles in different stages 35 days after graft means that once primordial follicles assembly occurs, subsequent development proceeds as normal. Neonatal development of rodent ovaries suffer generalized apoptosis of germinal cells (Hirshfield) before 
follicle assembly and early growth under a not well known mechanism. Former work from Arrau et al., grafting fetal ovaries under the kidney capsule demonstrates that the crucial event is that primordial follicles assembly take place and ovarian graft development were under regulation of steroid hormones.

To determine the effect of two different hormonal environments on the ovaries at the end of fetal life and start of folliculogenesis, we focused on morphological features of ovary grafted under previously unilateral orchidectomized males (UO+OG) or bilateral orchidectomized males $(\mathrm{BO}+\mathrm{OG})$. Lack of both testes in the male confers a gonadotrophic environment, with high levels of FSH and undetectable leves of testosterone while unilateral orchidectomy maintains adult testosterone and gonadotrophic levels, as can be see in Fig. 4. Neither of the treatments (UO+OG or $\mathrm{BO}+\mathrm{OG})$ affected primordial follicle assembly or early growth. But according to observations in vivo and in vitro models (Drummond), adverse effect of host androgens on the ovary graft is evident in growing secondary follicles that present more apoptosis and atresia in (UO+OG).

We also studied steroidogenic proteins and enzymes belonging to this biosynthetic pathway, such as StAR, $3 \beta-$ HSD, and aromatase (Payne \& Hales, 2004), these proteins were immunolocalized in the follicular wall suggesting steroid synthesis by theca and granulose cells. As expected $3 \beta$-HSD was mainly expressed in theca cells of growing secondary and tertiary follicles, while aromatase was specifically expressed in granulose cells of healthy antral follicles. This observation could be interpreted as the integrity of steroidogenic follicular unit in the grafted ovaries is maintained. Even more evident of the graft endocrine activity, are the observed peripheric levels of reproductive hormones in host males. The concentration of testosterone in serum of unilatheral orchidectomized males with ovarian graft suggest the aromatization of androgens by the graft follicular aromatase. On the other hand, it is well known that gonadal steroids alter the ability of the anterior pituitary gland to synthesize and/or secrete gonadotropins, as well as, the responsiveness to GnRH (Jeong \& Kaiser, 2006). The observed lower levels of FSH in bilaterally orchidectomized males with ovarian graft in comparison to bilaterally orchidectomized males without graft could be interpreted as consecuence of hormones released from the graft. If this effect is attibutable to ovarian steroid hormones or other peptidic mediator, could not be elucidated with the present results. Considering the total data reported here, there is evidence of integration of the ovary graft under the kidney capsule to the endocrine axis of the host male.

\section{ACKNOWLEDGEMENTS}

Authors (S.L.L. and D.I.B) would like to thank the División Académica, Universidad de Valparaíso for its support through the Programa de Estadías Académicas (2014-2015) and Dr. H. Urbanski from ONPRC-OHSU, USA, for allowed to acquire the expertise to develop the study of steroidogenic enzymes by immunohistochemistry.

LUNA, S. L.; PEÑA, S. I.; CUEVAS, A. J. \& BROWN, D. I. Integración endocrina de ovarios fetales trasplantados bajo la cápsula renal de hámster machos uni o bilateralmente castrados. Int. J. Morphol., 34(4):1271-1279, 2016.

RESUMEN: El desarrollo del ovario en mamíferos sufre importantes cambios durante el periodo perinatal, momento en el cual los folículos se ensamblan y comienzan a desarrollarse en un proceso no muy dilucidado que involucra señales endocrinas y paracrinas. Con el objetivo de investigar el efecto de dos ambientes hormonales sobre el desarrollo temprano del ovario de hamster, usamos un modelo de trasplante autólogo en el que ovarios fetales fueron trasplantados bajo la cápsula renal de machos receptores previamente castrados y hemicastrados. Después de 35 días de trasplante, los ovarios y el parénquima renal de los machos receptores no presentaron señales de rechazo. El ovario presentó folículos primordiales, primarios, secundarios y algunos folículos terciarios con características morfológicas similares a los ovarios de hembras controles de 35 días de edad. Folículos primarios y secundarios sanos de ambos grupos experimentales se encontraron en frecuencia y tamaño similar al de ovarios controles, los folículos terciarios fueron escasos tanto en controles como en ovarios trasplantados, siendo en éstos principalmente atrésicos. PCNA, un marcador de proliferación celular, fue detectado por inmunohistoquímica en células granulosas de folículos en crecimiento, mientras que caspasa 3 activa, un marcador de apoptosis, fue evidente en folículos secundarios. Por otra parte, inmunoreactividad para proteínas esteroidogénicas, StAR, 3-3HSD y aromatasa, fue detectada en la pared folicular. Esta observación, junto a la disminución de niveles séricos de FSH, sin cambios importantes en los niveles de testosterona en machos castrados que recibieron trasplantes ováricos, y la disminución en los niveles de testosterona sin cambios en los niveles de FSH en machos hemicastrados con trasplantes ováricos, sugiere que el ovario no solo produce hormonas esteroidales sino que además éstas modifican los niveles hormonales del macho receptor del trasplante. En conclusión, este modelo de trasplante autólogo agrega información del desarrollo ovárico temprano cuando éste se desarrolla bajo la cápsula renal de machos entregando evidencia de la integración funcional del ovario trasplantado al eje endocrino de los machos receptores.

PALABRAS CLAVE: Ovario; Foliculogénesis; Esteroidogénesis; Trasplante ovárico; Hámster. 


\section{REFERENCES}

Arrau, J.; Roblero, L.; Cury, M. \& González, R. Effect of exogenous sex steroids upon the number of germ cells and the growth of foetal ovaries grafted under the kidney capsule of adult ovariectomized hamsters. J. Embryol. Exp. Morphol., 78:33-42, 1983

Caldwell, B. V.; Pawling, R. S. \& Wright, P. A. Reestablishment of ovarian periodicity after transplantation to the Syrian hamster cheek pouch. Proc. Soc. Exp. Biol. Med., 123(2):551-3, 1966.

Chihal, H. J.; Bast, J. D.; Stone, S. C. \& Peppler, R. D. Plasma estradiol17beta, progesterone, FSH, LH and follicular development in castrated female rats with subcutaneous ovarian autografts. Biol. Reprod., 15(3):406-13, 1976.

Detre, S.; Saclani Jotti, G. \& Dowsett, M. A "quickscore" method for immunohistochemical semiquantitation: validation for oestrogen receptor in breast carcinomas. J. Clin. Pathol., 48(9):876-8, 1995.

Drummond, A. E. The role of steroids in follicular growth. Reprod. Biol. Endocrinol., 4:16, 2006.

Felicio, L. S.; Nelson, J. F.; Gosden, R. G. \& Finch, C. E. Restoration of ovulatory cycles by young ovarian grafts in aging mice: potentiation by long-term ovariectomy decreases with age. Proc. Natl. Acad. Sci. U. S. A., 80(19):6076-80, 1983.

Fulton, G. P. The Golden Hamster in Biomedical Research. In: Hoffman, R. A.; Robinson, P. F. \& Magalhaes, H. (Eds.). The Golden Hamster: Its Biology and Use in Medical Research. Ames, Iowa State University Press, 1968.

Gabe, M. Techniques Histologiques. Paris, Masson, 1968. pp.67-100.

Goodman, L. Observations on transplanted immature ovaries in the eyes of adult male and female rats. Anat. Rec., 59(2):223-51, 1934.

Gore-Langton, R. E. \& Armstrong, D. T. Follicular Steroidogenesis and its Control. In: Knobil, E. \& Neill, J. D. (Eds.). The Physiology of Reproduction. 2nd ed. New York, Raven Press, 1994. pp.571-627.

Gosden, R. G.; Boulton, M. I.; Grant, K. \& Webb, R. Follicular development from ovarian xenografts in SCID mice. J. Reprod. Fertil., 101(3):619-23, 1994.

Graham, J. D. \& Clarke, C. L. Physiological action of progesterone in target tissues. Endocr. Rev., 18(4):502-19, 1997.

Greenwald, G. S. \& Roy, S. Follicular Development and its Control. In Knobil, E. \& Neill, J. D. (Eds.). The Physiology of Reproduction. 2nd ed. New York, Raven Press, 1994. pp.629-725.

Henzl, M. R.; Chang, C. C.; Sundaram, K. \& Kincl, F. A. The influence of castration and neonatally administered steroids on the development of transplanted ovarian tissue under the kidney capsule in male rats and hamsters. Acta Endocrinol. (Copenh.), 66(3):547-57, 1971.

Hirshfield, A. N. Development of follicles in the mammalian ovary. Int Rev. Cytol., 124:43-101, 1991.
Hsueh, A. J.; Kawamura, K.; Cheng, Y. \& Fauser, B. C. Intraovarian control of early folliculogenesis. Endocr. Rev., 36(1):1-24, 2015.

Jeong, K. H. \& Kaiser, U. B. Gonadotropin-Releasing Hormone Regulation of Gonadotropin Biosynthesis and Secretion. In: Challis, J. R. G.; de Kretser, D. M.; Neill, J. D.; Pfaff, D. W.; Plant, T. M.; Richards, J. S. \& Wassarman, P. M. Knobil and Neill's Physiology of Reproduction. 3rd ed. San Diego, Elsevier, 2006. pp.1635-701.

Mangoushi, M. A. Contiguous allografts of male and female gonadal primordia in the rat. J. Anat., 123(Pt. 2):407-13, 1977.

McGee, E. A. \& Hsueh, A. J. Initial and cyclic recruitment of ovarian follicles. Endocr. Rev., 21(2):200-14, 2000.

McGowan, L. \& Davis, R. H. Intrasplenic ovarian grafts in Syrian hamsters and peritoneal fluid cellular distribution. Proc. Soc. Exp. Biol. Med., 134(2):507-9, 1970.

Payne, A. H. \& Hales, D. B. Overview of steroidogenic enzymes in the pathway from cholesterol to active steroid hormones. Endocr. Rev., 25(6):947-70, 2004

Richards, J. S. Hormonal control of gene expression in the ovary. Endocr. Rev., 15(6):725-51, 1994

Sitzmann, B. D.; Brown, D. I.; Garyfallou, V. T.; Kohama, S. G.; Mattison, J. A.; Ingram, D. K.; Roth, G. S.; Ottinger, M. A. \& Urbanski, H. F. Impact of moderate calorie restriction on testicular morphology and endocrine function in adult rhesus macaques (Macaca mulatta). Age (Dordr.), 36(1):183-97, 2014

Uilenbroek, J. T.; Tiller, R.; de Jong, F. H. \& Vels, F. Specific suppression of follicle-stimulating hormone secretion in gonadectomized male and female rats with intrasplenic ovarian transplants. J. Endocrinol., 78(3):399-406, 1978

Walters, K. A; Allan, C. M. \& Handelsman, D. J. Androgen actions and the ovary. Biol. Reprod., 78(3):380-9, 2008.

Correspondence to:

Selva Leticia Luna

Escuela de Química y Farmacia

Facultad de Farmacia

Universidad de Valparaíso

Av. Gran Bretaña 1093

Playa Ancha

Casilla 5001

Valparaíso

CHILE

Email: leticia.luna@uv.cl
Received: 01-08-2016

Accepted: 20-09-2016 